\title{
Does Early Marriage Make Women Happy? a Phenomenological Finding from Madurese Women
}

\author{
Yudho Bawono \\ Lecturer of Psychology Study Program, Department of Social and Cultural Sciences, \\ Faculty of Social and Cultural Sciences, Universitas Trunojoyo Maduralndonesia \\ yudho.bawono-2016@psikologi.unair.ac.id
}

Suryanto

Faculty of Psychology, UniversitasAirlangga

suryanto@psikologi.unair.ac.id

\begin{abstract}
Research on marriage has been pretty much done, including research on early marriage, particularly in Madura. Research on early marriage in Madura is exciting to do because this kind of marriage backed by a keen understanding of Islam, that if a child who is consider baligh (grown up) means they can be married. Madurese people believe in matchmaking as well as the existence of a belief, called sangkal (if the women reject the proposal from the male then the woman will be an old maid or ta' paju lake'). This study aims to describe the happiness of Madurese women who married early in achieving, using a qualitative method with phenomenological approach. Research participants are Madurese women who are married under the age of 18 , live in Madura, and are willing to be involved in research. Data collection used semi-structured interviews. The results of this study indicated that women from Madura can achieve happiness in their early marriage. This finding is different from other studies that found the occurrence of problems in the early marriage.
\end{abstract}

Keywords: baligh, sangkal, ta' paju lake'

Received 3 January 2019/Accepted 5 March 2019 @JEHCP All rights reserved

\section{Introduction}

Humans throughout their life span will pass through several stages of development, ranging from prenatal to old age (Hurlock, 1994; Zulkifli, 200I; Santrock, 2007) where one of the important periods throughout their life span is adolescence (Krori, 20II). Adolescence is divided into early adolescence (12-15 years), middle adolescence (I5-19 years), and late adolescence (19-22 years) (Mönks, Knoers, and Haditono, 200I). In Indonesia, adolescents 
who should still carry out developmental tasks in the form of preparing marriage and family (Havighurst in Hurlock, 1994; Havighurst in Agustiani, 2009) actually have carried out one of the developmental tasks of their adult life, namely marriage. Mönkset al. (200I) even mention the condition of these adolescents with the term "adolescence shortened" because they are married, do not continue school, work, and enter adulthood in adolescence.

Existing data shows that in Indonesia, marriage in adolescence, known as early marriage is still a lot happening. Data from the National Family Planning Coordinating Board (BKKBN) shows the high marriages under the age of 16 in Indonesia, reaching $25 \%$ of the number of marriages available. Data from Bappenas also shows that of the 2 million marriages, $34.5 \%$ are included in the category of early marriage, where the highest data is in East Java, higher than the national average of $39 \%$. According to the East Java Province BKKBN Youth Section Head, most early marriages occur in Madura, which is around 60\% and evenly distributed in four districts: Bangkalan, Sampang, Pamekasan, and Sumenep (Sakdiyah \& Ningsih, 20I3).

Based on these data, early marriage still occurs on Madura Island because Madurese communities still hold a matchmaking (pajhudan) tradition (Sakdiyah \& Ningsih, 20 I3; Rahayu \& Bawono, 2017). Early marriage especially for Madurese women continues to occur also due to the beliefs held by the community. Bahrudin's study (2016) in Banjarbillah Village, Tambelangan Subdistrict, Sampang Regency, Madura found that women who have reached the age of I5-18 years and are unmarried, they will be a source of public gossip. They were ridiculed by the nickname of sangkal that there were no more young men who were willing to marry the girl for a long time (ta 'paju lake'). Parents who have a psychological burden if their daughters become "spinsters" (not sold out/ tak laku-laku) eventually make parents immediately marry off their children (Sidiq, 2003; Sumbulah \& Jannah, 20I2; Bahrudin, 20I6).

In addition, according to Bahrudin (2016) based on his research in Banjarbillah Village, Tambelangan Subdistrict, Sampang Regency found that villagers believed that friendship between men and women who were not bound by marriage was a sinful act and could cause slander. Villagers consider marriage to be an obligation of Muslims and someone must be married if he has reached a sufficient age (baligh). If there are women who have reached the age of I5-18 years and are unmarried, the woman will become a source of gossip from the 
villagers. This statement is reinforced by Rachmad (2017) which states that Madurese consider marriage to be an individual's rights and obligations, not the state that regulates it. The truth of early marriage is considered as a form of moral embodiment of Islamic Madurese society and a cultural agreement in Madurese society. Therefore, early marriage can be a cultural relativism of the Madurese community. Rachmad (2017) even said that if the government would not be easy to regulate the Madurese people who have a strong Islamic culture, because the culture is still upheld and maintained by the next generation of Madurese people.

At present, early marriage in Indonesia has become an issue that has caught the attention of various child and women's observer institutions. Moreover, when he refused to submit a revision to the Marriage Law No. I Th. 1974 specifically in increasing the age of women's marriages from 16 years to 18 years by the Constitutional Court (Setyawan \& Herdiana, 2016; Jawa Pos, 2017; Kompas, 2017b). Efforts to submit a revision to the law itself because it is based on various problems caused by the existence of early marriage such as disharmony, lack of awareness to be responsible in domestic life (Jannah, 20II), its impact on reproductive health (Sumbulah \& Jannah, 2012) access to education for children who get married early (Sakdiyah \& Ningsih, 20I3), population outbreaks, economic, psychological, domestic violence and divorce problems (Setyawan \& Herdiana, 2016; Kompas, 20 I7a).

However, unlike previoeus explanation, in Madura this early marriage does not always bring up problems like the previous findings mentioned above. The Zumriyah (2015) study in Larangan Luar Village, Larangan Subdistrict, Pamekasan Regency, Madura found that couples who married early, could still live happily, peacefully and harmoniously. The following is an excerpt of an interview with his informant who was married at the age of 16 :

"I was first not ready to get married, because I felt I was still a child. But Alhamdulillah, until now my family and I live happily, peacefully and harmoniously, yes even though said people get married when they are young, they are vulnerable to divorce. In my opinion, getting married at an early age or getting married at the age of an adult, if the name of the problem is in the family, surely it will be faced only the husband and wife must be smart to find the best way to solve it, so that a happy family is created. No problem with problems, multiply thankful for the 
sustenance, good communication. The happiness of the family depends on the individual undergoing mbak ..." (interview with AN on March I3, 20I5).

("Saya sih pertamanya tidak siap menikah, karena saya merasa masih anak-anak.Tapi Alhamdulillah sampai sekarang saya dan keluarga hidup bahagia, tenteram dan harmonis, yaaa meskipun kata orang menikah waktu muda itu rentan dengan cerai gitu. Menurut saya sih menikah di usia dini ataupun menikah di umur dewasa kalau yang namanya masalah dalam keluarga, pasti akan dihadapi hanya saja pasangan suami istri tersebut harus pintar-pintar mencari cara yang terbaik untuk menyelesaikannnya agar tetap tercipta keluarga yang bahagia. Engak dhing bedepermasalahan, perbanyak bersyukur atas rezeki yang ada, komunikasi yang baik. Kebahagiaan keluarga itu kan tergantung dari individu yang menjalani mbak...") (wawancara dengan AN pada tanggal 13 Maret 2015).

A similar opinion was expressed by an Madurese woman from Errabu Village, Bluto Subdistrict, Sumenep Regency, through the explanation of Melati (I7 years). The following is the quotation result of the interview:

"Alhamdulillah ... happy, happy. It turned out that the choice of parents was not as people say. He said it's not good sir, Alhamdulillah, good parents choice. Meet me with him ... "(interview with Melati on June 2, 20I8).

(“Alhamdulillah..senang, bahagia. Ternyata pilihan orangtua itu tak se..seperti kata orang. Katanya tak baik ya pak ya..Alhamdulillah pilihan orangtua baik. Mempertemukan saya dengan dia..") (wawancara dengan Melati pada tanggal 2 Juni 20I8).

This statement about happy early marriage is also strengthened by the findings of Hairi (2009) in his research in the Bajur Village, Waru Subdistrict, Pamekasan Regency as follows:

"Indeed, most of the village of Bajur still practice marriage at a young age and even underhanded marriages are often carried out, but the marriage has until now been a permanent majority and even very few have ended in divorce, so marriage can be done at a young age or at an age it is mature that the important thing is 
accompanied by sincere intention and to improve our worship to Allah SWT' (interview with $\mathrm{AH}$ on August 27, 2008).

(“Memang kebanyakan masyarakat Desa Bajur ini masih mempraktekkan pernikahan di usia muda dan bahkan pernikahan di bawah tangan sering dilakukan, namun pernikahan tersebut hingga sekarang mayoritas kekal dan bahkan sedikit sekali yang berakhir pada perceraian, jadi pernikahan itu dapat dilakukan pada usia muda ataupun pada usia yang sudah matang yang penting dibarengi oleh niat yang sungguh-sungguh dan demi meningkatkan ibadah kita kepada Allah SWT”) (wawancara dengan AH pada tanggal 27 Agustus 2008).

Based on the description above it can be said that the phenomenon of early marriage in Madura has its own uniqueness that is closely related to the local culture and beliefs of its citizens. In addition, the phenomenon of early marriage in Madura is also becoming increasingly interesting to study because various problems in early marriage do not always occur in Madurese women. Some other research data actually shows that Madurese women who marry early can also achieve happiness and harmony in their formal marriages. This raises an understanding of why addressing the issue of early marriage in Madura is not easy to do.

Revealing how happiness can be achieved based on the perspective of individuals who experience the phenomenon of early marriage, will open up opportunities for better information on the psychological development of individuals amid certain social symptoms in society. The author is aware of the possibility of different interpretations of the direction and purpose of this research. Anticipating this, affirmation is given at the end of this background description that the results of this study will not aim to support the occurrence of early marriage in Madura even though Madurese women who marry early can achieve happiness. The narrative obtained from the participants' research experience is expected to be an important clue how in conditions of marriage that are not ideal, one can strive for happiness, so that ultimately the individual can minimize the problems in his official marriage so that it does not end in divorce. 


\section{Method}

\section{Participant}

In this study, we used purposive sampling, in which the process of selecting participants was performed by considering certain things based on research objectives. In this study, the participants were following characteristics: (a) Madurese women; (b) when married 18 years and under; (c) marriage age less than 10 years; (d) live in Madura; and (e) willing to be involved in research. We selected two participants because who fulfills the above characteristics. The two participants are Bunga and Mawar. The participants married I8 years and under, marriage age less than 10 years, and live in Madura.

Design

This study used qualitative research methods with a phenomenological approach, qualitative research that describes the general meaning of a number of individuals to their various life experiences related to concepts or phenomena (Creswell, 20I5; Hanurawan, 20I6).

\section{Procedure}

In phenomenological research, interview guides are expected to contain neutral questions or questions that reflect ephocē. Researchers can deepen participants' answers using prompting and probing techniques. Prompting means asking for a prompt, namely a question intended to encourage participants to tell more about their experiences, while probing means asking for a probe that is a question intended to ask for further clarification of certain terms or expressions that are not clear or still vague (Kahija, 20I7).

\section{Data Analysis}

At the time of data collection, researchers interacted with participants as the main respondents. In phenomenological research the form of interview commonly used is semistructured interviews. The characteristic of semi-structured interviews is the use of interview guides/ interview protocols (Kahija, 2017). In this phenomenological study, we analyzed using the Hermeneutic method. This method focuses on understanding the meaning of one's experience by looking for themes from available data. 


\section{Result}

Based on the interview with our participants, we found several common patterns or themes: (I) reasons for marriage; (2) happiness; and (3) unhappiness. The three themes are discussed in detail below:

\section{Reasons for marriage}

The reasons for marriage proposed by the two participants were almost the same. Both say if the reason they are married is because they love their partner. Bunga, our participant who lives in Mangkon Selatan Village, Arosbaya Subdistrict, Bangkalan Regency, said that if the reason for marriage was because of (a) married because there is no fee for school; (b) married because she want to have a family; and (c) married on her own accord. This is the quote for the interview:

\footnotetext{
"Yes, the parents are in ... (silent)yes ... asked, yes ... if you want to go to school, you can't afford it ... your parents ... there are people who marry" (Bunga, 19-10-2018, interview I:I4-16)

("Iya sama orang tua kan di..(terdiam) iya.. ditanyain, ya.. kalau mau sekolah gak mampu emm.. orangtuanya ya.. mutusin ada orang yang menikah”) (Bunga, 19-10-2018, wawancara I:I4-I6)
}

Then Bunga also said:

"Yes ... dozen married, why want you ... want your family to do that" (Bunga, 19-1020I8, interview $1: 21$ )

("Yaa..mutusin menikah yaa pengin yaa.. pengin keluarga lah gitu”) (Bunga, 19-1020I8, wawancara I:2I)

Meanwhile Mawar, our participant who married at the age of 15 from Mangkon Selatan Village, Arosbaya Subdistric, Bangkalan Regency says:

"Happy from the first marriage based on love is not the match of parents. By your own will, happy ... "(Mawar, I I-I7-20 I8, interview 2: I-4). 
("Bahagia dari pertama menikah didasari cinta bukan perjodohan orang tua. Atas kemauan diri sendiri yah bahagia..”) (Mawar, I7-II-20I8, wawancara 2:I-4).

\section{Happiness}

Even though married early, Madurese women can also achieve happiness. This happiness can be achieved by Madurese women if Madurese women have a lot of money and always want to be with their husbands. The following is an excerpt from the interview that we found in the field:

\footnotetext{
"Happy if you have a lot of money, happy if you are with your husband. Now if you are married young you are left chasing after wealth, if you are now a person because of that the husband of a young child even though you are married is important to you, yes, after 2 days left sailing. Only impregnate later if it's been 9 months when you have a child. For me, I didn't do it, yeah, because together I used to work together again when work and work here could be seen by the eye rather than looking for husbands who left for the land of people "(Mawar, 29-10-2018, interview I: 2I-28).
}

(“Bahagia kalau punya banyak uang, bahagia kalau bareng sama suami. Sekarang kalau menikah muda ditinggal kan sekarang ngejar harta, kalau orang sekarang karena itu suami layaran anak walupun muda dinikahkan yang penting kaya ya sudah setelah 2 hari ditinggal berlayar. Hanya menghamili nanti kalau udah 9 bulan pas dateng sudah ada anak.Kalau saya dulu gak gitu, yah karena bersama terus biasa bareng lagi kalau kerja mending kerja di sini bisa dilihat mata daripada nyari suami yang berangkat ke negeri orang")(Mawar, 29-10-2018, wawancara I:21-28).

\section{Unhappiness}

Early marriage not only makes happy Madurese women, but early marriage also brings unhappiness. This is as stated by Mawar as follows: 
"... In marriage there is a happy person who is not happy, sir, who is not happy like that, sir, the economy is not fixed, it is not strong enough for its own home and its work is still not the same" (Mawar, II-I7-20I8, interview 2: 28-3I).

(“...dalam pernikahan ada orang yang bahagia ada yang gak bahagia pak, yang gak bahagianya seperti tadi pak, perekonomian belum tetap, belum kuat buat rumah sendiri dan pekerjaanya belum tetep yang begitulah”) (Mawar, I7-II-20I8, wawancara 2:28$31)$.

\section{Discussion}

During adolescence, what is considered important is happiness (Hurlock, 1994) where happiness itself is interpreted as positive emotions that include positive feelings and positive activities. This happiness can be seen in three dimensions, namely: happiness towards the past, optimism for the future, and happiness in the present (Seligman, 2005). According to Azizah (2013) this happiness will determine happiness in the age of subsequent development. Happiness is an important thing in a relationship. Happiness is a benchmark for someone in a relationship whether they feel safe and comfortable in the relationship. Married people tend to be happier than unmarried people (Myers in Papalia, Old, \& Feldman, 2009) including those who married early.

On Madura island, the rate of early marriage is high enough. It because a several factors. First, early marriage is because Madurese people still hold the tradition of matchmaking (Hairi, 2009; Sakdiyah \& Ningsih, 20I3; Munawara, Yasak, \& Dewi, 20I5; Rahayu \& Bawono, 2017). The arranged marriages are carried out since they were in the womb (Sidiq, 2003; Sadik, 20I4; Munawara et al., 20I5; Fawaid \& Hadi, 20I5; Rohmah, 2016) which are called bhāākāl ekakoãghĭ and have moved on in childhood, known as the tan-mantanan tradition, is a tradition of young brides (4-10 years old) as practiced by adult brides, which is carried out from the beginning of the engagement process (bebekalan) to the wedding reception process. The difference is that the absence of obedience is the same as that of an adult bride, so they have not been bound as husband and wife (Nuri, 2016; Rohmah, 2016). 
Second, there is still a lot of early marriage in Madura because of the trust held by the local community. This belief is related to the importance of the matchmaking process so that girls can get married soon. Unmarried women will be ridiculed with sangkal that there are no more young men who are willing to marry the girl for a long period of time (ta 'paju lake'), so that from this nickname abstinence for a woman refusing an application from a man who came to apply (Bahrudin, 2016; Susilo, 2017). Parents who have a psychological burden if their daughters become "spinsters" (not sold out/ tak laku-laku) finally make a decision to immediately marry off their children (Sumbulah \& Jannah, 20I2; Bahrudin, 2016). Sidiq's (2003) study in Panaongan and Lebbeng Barat Villages, Pasongsongan Subdistrict, Sumenep Regency even found that if there was a girl who refused her marriage, the girl in addition to receiving sanctions in the form of not being greeted by her family, would not intervene again in the next match. This shows that parents will "let go of their hands" ("lepas tangan") towards the continuation of their daughter's life.

Third, early marriage that still occurs a lot for Madurese women is also inseparable from the strong influence of Islam (Fawaid \& Hadi, 20I5; Rachmad, 20I7) and culture that is still held firmly by Madurese communities (Sakdiyah \& Ningsih, 2013; Yunitasari, Pradanie, \& Susilawati, 2016; Rachmad, 2017). This was stated by Bahrudin (2016) based on his research in Banjarbillah Village, Tambelangan Subdistrict, Sampang Regency. Villagers believe that friendship between men and women who are not bound by marriage is a sin and can cause slander. Villagers consider marriage to be an obligation of Muslims and someone must be married if he has reached sufficient age. In addition, if there are women who have reached the age of 15-18 years and are unmarried, the woman will become a source of gossip from the villagers.

This statement is reinforced by Rachmad (2017) which states that Madurese consider marriage to be an individual's rights and obligations, not the state that regulates it. The truth of early marriage is considered as a form of moral embodiment of Islamic Madurese society and a cultural agreement in Madurese society. Therefore, early marriage can be a cultural relativism of the Madurese community. Rachmad (2017) even said that if the government would not be easy to regulate the Madurese people who have a strong Islamic culture, because the culture is still upheld and maintained by the next generation of Madurese people. 
The three factors that strengthen the height of early marriage on Madura based on previous research (Hairi, 2009; Sakdiyah \& Ningsih, 2013; Munawara et al., 2015; Fawaid \& Hadi, 2015; Bahrudin, 2016; Yunitasari et al., 2016; Rachmad, 2017; Rahayu \& Bawono, 2017; Susilo, 2017) revealed that the phenomenon of early marriage in Madura has its own uniqueness that is closely related to the local culture and beliefs of its citizens. This raises an understanding of why addressing the issue of early marriage in Madura is not easy to do.A number of literatures have examined that early marriage can cause problems for couples such as: fighting, persistent quarrels, clashes between husband and wife (Maemunah, 2008; Aryanto, 2017), disharmony (Jannah, 20II), domestic violence and divorce (Setyawan \& Herdiana, 2016). However, the phenomenon that appears in Madura is interesting because these problems are not always true for Madurese women who marry early because they can achieved happiness in their early marriage.

This happiness can be achieved by Madurese women because in their early marriages, two research participants said that their marriage was their own desire, not because of coercion from parents. This finding is interesting because previous findings suggest that early marriage in Madura occurred because of arranged marriages by parents (Hairi, 2009; Sakdiyah \& Ningsih, 2013; Munawara et al., 2015; Rahayu \& Bawono, 2017). So that it can be said that their marriage can be happy because they are married without coercion in the form of matchmaking. Even one participant also said that her marriage occurred because of feelings of love for her husband. Thus it can be concluded that marriage on the basis of love and without coercion contributes to the achievement of happiness in their marriage.

Apart from being love and without coercion to get married, happiness in early marriage for Madurese women can also be achieved if they have a lot of money. This is as stated by Peterson and Seligman (2005) that achieving happiness is not always associated with mere assets, whether in the form of money or material.Diener, Sandvik, Sidlitz, and Diener (1993) also say that money has a positive correlation with happiness, where the higher the money, the higher the happiness.

However, besides this Madurese woman can be happy with her marriage, in this study it was also found that they would be unhappy if they did not have money. This is as stated by Tang 
(1995) that for those who have limited money, this condition can trigger anxiety and unhappiness. This unhappiness can be experienced by Madurese women because they are not yet economically stable, do not have their own homes, and their husbands do not have permanent jobs.

\section{Conclusion}

Early marriage in Madura has its own distinctiveness compared to other regions. Several factors that influence it include: (I) Madurese people still hold the tradition of matchmaking. The arranged marriages are carried out since they were in the womb or childhood; (2) the trust held by the local community called sangkal that there are no more young men who are willing to marry the girl for a long period of time (ta 'paju lake'); (3) inseparable from the strong influence of Islam and culture that is still held firmly by Madurese communities. Someone must be married if she has reached sufficient age (baligh).

This research shows that Madurese women can achieve happiness in their early marriages. This is indicated by marriage based on their will and having a lot of money.However, Madurese women can also feel unhappiness if the economy is not yet fixed, they cannot make their own homes and their husbands' jobs are not yet fixed.This research still has limitation. One of it is the research location only taking Bangkalan Regency, while Madura consists of four districts namely Bangkalan, Sampang, Pamekasan, and Sumenep. Thus, further research can be carried out in the other three districts besides Bangkalan Regency by involving participants who also came from three other districts. Further researchers can also use methods or approaches other than qualitative methods and phenomenology approaches, for example with an ethnographic approach.

\section{Acknowledgement}

The author would like to thank Novia, Dzinurain, Chair of the Psychology Doctoral Program, Faculty of Psychology, Airlangga University and the Education Fund Management Institute (LPDP) for the support given in writing this article. 


\section{References}

Agustiani, H. (2009). Psikologi perkembangan: Pendekatan ekologi kaitannya dengan konsep diri dan penyesuaian diri pada remaja.(Developmental psychology: Ecological approach related to self concept and self-adjusment among teenagers). Bandung: PT Refika Aditama

Aryanto.(2017). Remaja siap nikah belum tentu dewasa. (Teenagers ready for marriage are not necessarily adults). Intisari. September 2017, 70-78

Azizah. (20I3). Kebahagiaan dalam permasalahan di usia remaja (Penggunaan informasi dalam pelayanan bimbingan individual). (Happiness in problems in adolescence (Use of information in individual guidance services)).Konseling Religi: Jurnal Bimbingan Konseling Islam. 4(2), 295-3I 5

Bahrudin.(2016). Konflik intrapersonal remaja putri yang dipaksa menikah dini di Desa Banjarbillah.(Intrapersonal conflict of young women forced to marry early in Banjarbillah village). Unpublished undergraduate thesis.Bangkalan: Program Studi Psikologi Universitas Trunojoyo Madura

Creswell, J. W. (20I5). Penelitian kualitatif \& desain riset: Memilih diantara lima pendekatan. Edisi 3.(Qualitative research \& research design: Choose between five approaches). Third Edition.Yogyakarta: Pustaka Pelajar

Diener, E., Sandvik, E., Seidlitz, L., \& Diener, M. (1993). The relationship between income and subjective well-being: Relative or absolute? Social Indicators Research. 28(195), 195-223

Fawaid , F. \& Hadi, M. H. A. (20I5). Pelaksanaan nikah ngodheh (Studi komparasi hukum Islam dengan hukum adat) di Desa Bangkes Kecamatan Kadur Kabupaten Pamekasan Madura.(Implementation of ngodhehmarriage (Comparative study of Islamic law with customary law) in Bangkes Village, Kadur Subdistrict, Pamekasan Madura Regency).Panggung Hukum. I(2), 2 I 7-247

Hairi. (2009). Fenomena pernikahan di usia muda di kalangan masyarakat muslim Madura (Studi kasus di Desa Bajur Kecamatan Waru Kabupaten Pamekasan). (The phenomenon of marriage at a young age in the Muslim community of Madura (Case study in the Bajur Village, Waru District, Pamekasan Regency)). Unpublished undergraduate thesis.Yogyakarta: Fakultas Ushuluddin Universitas Islam Negeri Sunan Kalijaga

Hanurawan, F. (2016).Metode penelitian kualitatif untuk ilmu psikologi.(Qualitative research methods for psychology).Jakarta: PT. Raja Grafindo Persada

Hurlock, E. B. (1994). Psikologi perkembangan: Suatu pendekatan sepanjang rentang kehidupan.(Developmental psychology: An approach throughout the life span). Jakarta: Erlangga 
Jannah, F. (20I I).Pernikahan dini dalam pandangan masyarakat Madura (Studi fenomenologi di Desa Pandan Kecamatan Galis Kabupaten Pamekasan).(Early marriage in the view of the Madurese community (Phenomenological study in Pandan Village, Galis Subdistrict, Pamekasan Regency)). Unpublished undergraduate thesis. Malang: Jurusan Al-Ahwal AI-Syakhshiyyah Fakultas Syari'ah UIN Maulana Malik Ibrahim Malang

Jawa Pos. (2017). Naikkan batas usia nikah perempuan. (Increase the age of marriage for women). 4 November 2017. HIm. 12, 2-6

Kahija, Y. F. L. (2017). Penelitian fenomenologis: Jalan memahami pengalaman hidup.(Phenomenological research: The way to understand life experiences). Yogyakarta: Penerbit Kanisius

Kompas. (2017a). Lima daerah jadi percontohan, perkawinan usia anak rentan timbulkan masalah sosial dan kesehatan. (Five regions became a pilot, vulnerable age marriage caused social and health problems).22 April 2017. HIm. 12

Kompas. (20l7b). Masa depan anak hancur, gerakan bersama stop perkawinan anak harus sampai daerah.(The future of the child is destroyed, the movement to stop the marriage of the child must reach the area). 4 November 2017. HIm. 12

Krori, Smita Deb. (20II). Developmental Psychology dalam Homeopathic Journal.4(3), January $2011 \quad$ (tersedia http://www.homeorizon.com/homeopathicarticles/psychology/developmental-psychology I4 Februari 20I2)

Maemunah. (2008). Hubungan antara faktor pendidikan remaja dan ekonomi keluarga dengan sikap remaja untuk memutuskan menikah di usia muda di Desa Prapag Kidul-LosariBrebes. (The relationship between teenage education and family economics with adolescent attitudes to decide to marry at a young age in the Prapag Kidul-LosariBrebes Village).Unpublished undergraduate thesis.Surakarta: Universitas Muhammadiyah Surakarta

Mönks, F. J., Knoers, A. M. P., \& Haditono, S. R. (200I).Psikologi perkembangan: Pengantar dalam berbagai bagiannya. (Developmental psychology: Introduction in various parts).Yogyakarta: Gadjah Mada University Press

Munawara,.Yasak, E. M., \& Dewi, S. I. (20I5).Budaya pernikahan dini terhadap kesetaraan gender masyarakat Madura.(Early marriage culture towards gender equality of Madurese society).Jurnal IImu Sosial dan IImu Politik. 4(3), 426-43I

Nuri, S. (20/6). Agresivitas remaja putri akibat tradisi tan mantanan di Desa Poteran Kecamatan Talango Kabupaten Sumenep. (The aggressiveness of young women due to the tradition of tan mantanan in Poteran Village, Talango District, Sumenep Regency).Unpublished undergraduate thesis.Bangkalan: Program Studi Psikologi Universitas Trunojoyo Madura 
Papalia., Olds., \& Feldman. (2009). Human development: Perkembangan manusia. Buku 2.Edisi 10.(Human development: Human development). Book 2.10 th Edition.Jakarta: Salemba Humanika

Peterson, C. \&Seligman, M. E. P. (2005).Character, strengths, and virtues: A handbook and classification. New York: Oxford University Press

Rachmad, T. H. (20I7). Kontestasi pernikahan dini dalam kajian budaya Madura. (dalam :Fenomena pernikahan dini di Madura.Editor: Kurniawati, N. D, Rachmad, T. H. \& Yuriadi). (Contestation of early marriage in the study of Madura culture. (in: The phenomenon of early marriage in Madura. Editors: Kurniawati, N. D, Rachmad, T. H. \& Yuriadi)). Malang : AE Publishing

Rahayu, W. Y. \& Bawono, Y. (2017).Emotion focus coping pada perempuan Madura yang menikah karena perjodohan. (Emotion focused coping on Madurese women who are married because of matchmaking). Prosiding.Bangkalan: Program Studi Psikologi Universitas Trunojoyo Madura

Rohmah, L. (2016). Penyesuaian pasangan yang dijodohkan sejak dalam kandungan di Desa Poteran, Talango, Sumenep.(Adjustment of the pair that has been arranged since the womb in Poteran Village, Talango, Sumenep). Unpublished undergraduate thesis. Bangkalan: Program Studi Psikologi Universitas Trunojoyo Madura

Sadik, A. S. (20I4). Memahami jati diri, budaya, dan kearifan lokal Madura. (Understand the identity, culture and local wisdom of Madura). Surabaya: Balai Bahasa Jawa Timur

Sakdiyah, H., \& Ningsih, K. (20/3). Mencegah pernikahan dini untuk membentuk generasi berkualitas preventing early-age marriage to establish qualified generation. Masyarakat, Kebudayaan dan Politik. 26(I), 35-54

Santrock, J. W. (2007). Perkembangan masa hidup.(Development of life).Jakarta: Erlangga

Seligman, M. E. P. (2005). Authentic happiness menciptakan kebahagiaan dengan psikologi positif. (Penerjemah: Nukman, E. Y). (Authentic happiness creates happiness with positive psychology. (Translator: Nukman, E. Y)). Bandung: Mizan

Setyawan, A.\& Herdiana, I. (2016).Kualitas hidup perempuan pulau Mandangin yang menikah dini.(The quality of life of Mandangin island women who married early).Jurnal Psikologi Kepribadian dan Sosial. 5(I), I-IO

Sidiq, M. (2003).Kekerabatan dan kekeluargaan masyarakat Madura Kecamatan Pasongsongan. Dalam Kepercayaan, magi, dan tradisi dalam masyarakat Madura.Penyunting: Soegianto. (The kinship and kinship of the Madurese community, Pasongsongan District.In Trust, magic, and tradition in Madurese society. Editor: Soegianto). Jember: Penerbit Tapal Kuda

Sumbulah, U. \& Jannah, F. (20I2).Pernikahan dini dan implikasinya terhadap kehidupan keluarga pada masyarakat Madura (Perspektif hukum dan gender).(Early marriage 
and its implications for family life in Madurese society (legal and gender perspective)). Egalita Jurnal Kesetaraan dan Keadilan Gender, 8(I), 83-I0I.

Susilo, S. (2017).Makna pernikahan dini bagi orang tua pada masyarakat pengemis di Dusun Pelanggaran, Brata Tinggi, Kecamatan Tlanakan, Kabupaten Pamekasan Madura.(The meaning of early marriage for parents in begging communities in Pelanggaran Hamlet, Brata Tinggi, Tlanakan District, Pamekasan Madura Regency).Prosiding Seminar Nasional Tahunan Fakultas IImu Sosial Universitas Negeri Medan Tahun 20I 7.I (I), 472-476

Tang, T. L. P. (1995). The development of a short money ethic scale: Attitudes toward money and pay satisfaction revisited. Personality and Individual Differences. 19(6), 809-816

Yunitasari, E., Pradanie, R., \& Susilawati, A. (2016). Pernikahan dini berbasis transkultural nursing di Desa Kara Kecamatan Torjun Sampang Madura (Early marriage based on transcultural nursing theory in Kara Village Sampang). Jurnal Ners. I I (2), I64-I69

Zulkifli. (200I). Psikologi perkembangan. (Developmental psychology). Bandung: PT Remaja Rosdakarya

Zumriyah, R. (2015). Keharmonisan keluarga pada pasangan yang menikah dini.(Studi kasus pasangan menikah dini di Desa Larangan Luar Kecamatan Larangan Kabupaten Pamekasan Madura.(Family harmony in couples who get married early (Case study of early married couples in Larangan Luar Village, Larangan District, Pamekasan Madura Regency)). Unpublished undergraduate thesis.Bangkalan: Program Studi Psikologi Universitas Trunojoyo Madura 